Introduction: Postimperial sovereignty games in the Nordic region

Adler-Nissen, Rebecca; Gad, Ulrik Pram

Published in:

Cooperation and Conflict

DOI:

$10.1177 / 0010836713514148$

Publication date:

2014

Document version

Early version, also known as pre-print

Citation for published version (APA):

Adler-Nissen, R., \& Gad, U. P. (2014). Introduction: Postimperial sovereignty games in the Nordic region. Cooperation and Conflict, 49(1), 3-32. https://doi.org/10.1177/0010836713514148 


\title{
Introduction: Postimperial sovereignty games in the Nordic region
}

Cooperation and Conflict 20I4, Vol. 49(I) 3-32

(C) The Author(s) 2014

Reprints and permissions: sagepub.co.uk/journalsPermissions.nav DOI: $|0.1| 77 / 00|08367| 35|4| 48$ cac.sagepub.com @SAGE

\author{
Rebecca Adler-Nissen \\ and Ulrik P Gad
}

\begin{abstract}
Benevolence, homogeneity and peace has never been the full story of the Nordic region. Building on a critical review of myths of 'Norden' in international relations theory and beyond (international political economy, security studies, regional and European integration theory and postcolonialism), we develop the framework of postimperial sovereignty games for understanding contemporary Nordic foreign policy and regional dynamics. We shift focus from the 'large' Nordic countries to the remnants of Nordic empires: Iceland, Greenland, the Faroe Islands and Åland. On the one hand, these polities struggle to enhance their independence - Iceland even after becoming a sovereign state; the other polities via self-government arrangements. On the other hand, the former colonies develop close relationships to a supranational European Union in their effort to achieve independent subjectivity. Contrasting the developments towards increased independence and European integration, the article demonstrates the importance of imperial legacies. Firstly, it challenges Norden as a model security community. Secondly, it questions the image of a harmonious Nordic welfare model based on equality and consensus in light of the experiences of Iceland, Greenland, the Faroe Islands and Åland. Finally, it suggests that no theory of European integration is complete without taking imperial and postimperial processes into account.
\end{abstract}

\section{Keywords}

Empire, European integration, Nordic region, postcolonialism, sovereignty games

\section{Introduction}

Are the Nordic countries different from the rest of Europe? For many theorists, policy analysts and politicians, the answer is obvious: Yes, of course! One chapter heading in a book on Nordic security simply reads 'The North Is Different' (Dörfer, 1997: 15). In Europe, Norden stands out: '[T] he Nordic countries will provide something qualitatively

\footnotetext{
Corresponding author:

Rebecca Adler-Nissen, Department of Political Science, University of Copenhagen, Øster Farimagsgade 5A, DK-I353 Copenhagen K, Denmark.

Email: ran@ifs.ku.dk
} 
different to the EU' (Miles, 1996b: 7). Indeed, '[t]he Nordics are often seen as a group by external actors' (Græger, 2011: 25), and the official homepage of Nordic intergovernmental cooperation reads, '[t]he Nordic countries have followed relatively similar institutional development patterns' (Norden.org, n.d.). But what makes the Nordic countries different? Firstly, it is commonly argued, the Nordic region does not have a lengthy and painful history of colonialism like the rest of Europe does. Unlike the United Kingdom and France, the Nordic states rejected a policy of imperialism. Or at least, so the story goes, in the Nordic region, empire is something of the past. The Danish and Swedish colonies were lost or sold (although the Danish colonies in the West Indies were only sold to the US in 1917). Arguably, the Nordic countries closed the chapter on imperialism when Norway, Finland and Iceland gained independence in the first half of the last century. Having turned its back on colonial and imperial adventures, Norden instead developed into a security community and the world's largest donor of development aid and contributed disproportionately to United Nations (UN) peacekeeping. Thus, 'the Nordic nations provided public goods to the world community ... [and] fancied themselves as mediators and healers' (Archer, 1996: 264-271; Browning, 2007: 33-35; Dörfer, 1997: 15-16; Ingebritsen, 2002; Miles, 1996b: 8). Secondly, and linked to this image of peaceful benevolence, is the understanding that the Nordic countries are exceptionally stable nation states. Observers claim that the high degree of homogeneity and equality in the Nordic states helps explain the development of advanced welfare systems (Bjørnskov, 2008). Domestic progress and regional peace combined resulted in a 'Nordic model' that could be actively exported (Archer, 1999: 62; Browning, 2008: 240; Mouritzen, 1995). Thirdly, the Nordic countries stand out when it comes to European integration. The Nordic countries are usually described as more EU-sceptic than other European countries (Archer, 2000; Miles, 1996a: 277; Raunio, 2007). It is often argued that this is due to a particularly strong national identity and attachment to national sovereignty. These three images - peacefulness, homogeneity and EU-scepticism - are often presented as entangled (Archer, 2000: 109; Bergman, 2007; Browning, 2008: 239; Kuisma, 2007; Lawler, 1997).

As with many headline stories, this one - emphasizing Nordic exceptionality - is overstated. This special issue claims that Nordic benevolence, homogeneity and peacefulness is not the full story. ${ }^{1}$ We point out the importance of the imperial legacies for understanding contemporary dynamics of Nordic foreign policy and regional interaction. Denmark and Sweden used to be the two dominant empires in the Nordic region, each ruling over their respective dependencies. Imperial logics continue to influence policymaking and identity politics today. This special issue examines hitherto understudied Nordic (post-)imperial territories and former colonies.

In using the notion of empire, we refer to a systematic domination of one society over others, as we saw in the 19th and 20th centuries when Europe dominated the rest of the world (Doyle, 1986: 20). Integral to imperial rule is that the various political entities that are governed by a centre often have different relations to the centre (Jordheim and Neumann, 2008: 10; Nexon and Wright, 2007). This variety of relations to the centre forms a starting point for a development in which 'modern empires have nation-state cores and ... subordinated peoples, in their turn, are also incorporated into modern systems of political action and belief, coming themselves to aspire to nationhood' (Shaw, 
2002: 329). Hence, a postimperial situation is one in which the imperial configuration is transformed beyond the original hierarchy and new identities, groups or even states emerge (see Neumann, 2014).

More specifically, this special issue shifts focus from the 'large' Nordic countries Sweden, Denmark, Norway and Finland - to the polities of Iceland, Greenland, the Faroe Islands and Åland, which are remnants of Nordic imperialism. These polities are struggling to enhance their independence. Iceland became a sovereign state in 1918 and finally shed the last formal bonds to Denmark (foreign and defence policy and a personal union with the King) in 1944, but the other polities have various forms of selfgovernment arrangements. At the same time, these polities are developing close relationships to a supranational EU and the international community more broadly. Iceland was accepted as a formal EU candidate in 2010, and while Greenland was the first and so far only 'country' to leave the EU in 1985, the debate on whether to join again never seems to die. Table 1 provides an overview of the cases addressed in this special issue.

Notwithstanding the political attention, the contrasting development towards increased independence on the one hand and European integration on the other has yet to be systematically investigated. As such, Norden constitutes a site for understanding bigger issues concerning sovereignty and the interplay between postimperial relations and European integration.

Today, both traditional and more radical international relations (IR) scholars are trapped with misleading interpretations of the Nordic region. Traditionalists, be they of realist or liberalist inclinations, tend to accept the image of the Nordic countries as particularly homogenous, peaceful, successful and benevolent as an accurate description (Archer, 2000: 109; Campbell et al., 2006; Katzenstein, 1996; Kuisma, 2007; Lawler, 1997). Constructivists and poststructuralists generally dismiss this self-image as an accurate description - only to tell the same story by examining it as a discourse. Paradoxically, constructivists and poststructuralists therefore end up with a similar image of a harmonious and peaceful Norden as traditionalists do (Bergman, 2007; Browning and Joenniemi, 2012; Hansen and Wæver, 2002; Joenniemi, 2007).

By exploring what we call 'postimperial sovereignty games', this special issue challenges established myths about the Nordic region in IR theory and advances an alternative perspective on the imperial legacies and present dynamics of sovereignty. The main aim of this special issue is not to explore the colonial past of the Nordic countries (for this, see Neumann, 2014; Keskinen et al., 2009). Instead, we examine how European integration and postimperialism intersect in the Nordic countries today. In doing so, we provide a systematic comparison of the triangular relationships between the EU, the four small polities, and their respective metropoles. As will become clear, just because Iceland is now a sovereign state, the historical relationships to Denmark and Norway (its former metropoles) still matter beyond what has traditionally been identified as an Icelandic nationalism in an 'unremitting struggle for its freedom' (Hálfdanarson, 2004: 131, 132, 137; Thorhallsson, 2004: 191). We explore how these remnants of the Nordic empires formally sovereign Iceland and the three home-rule countries - use the EU in their efforts to achieve independent subjectivity in a way formed by each of their particular postcolonialities. In addition, we explore how the EU and the former metropoles deal with them. 


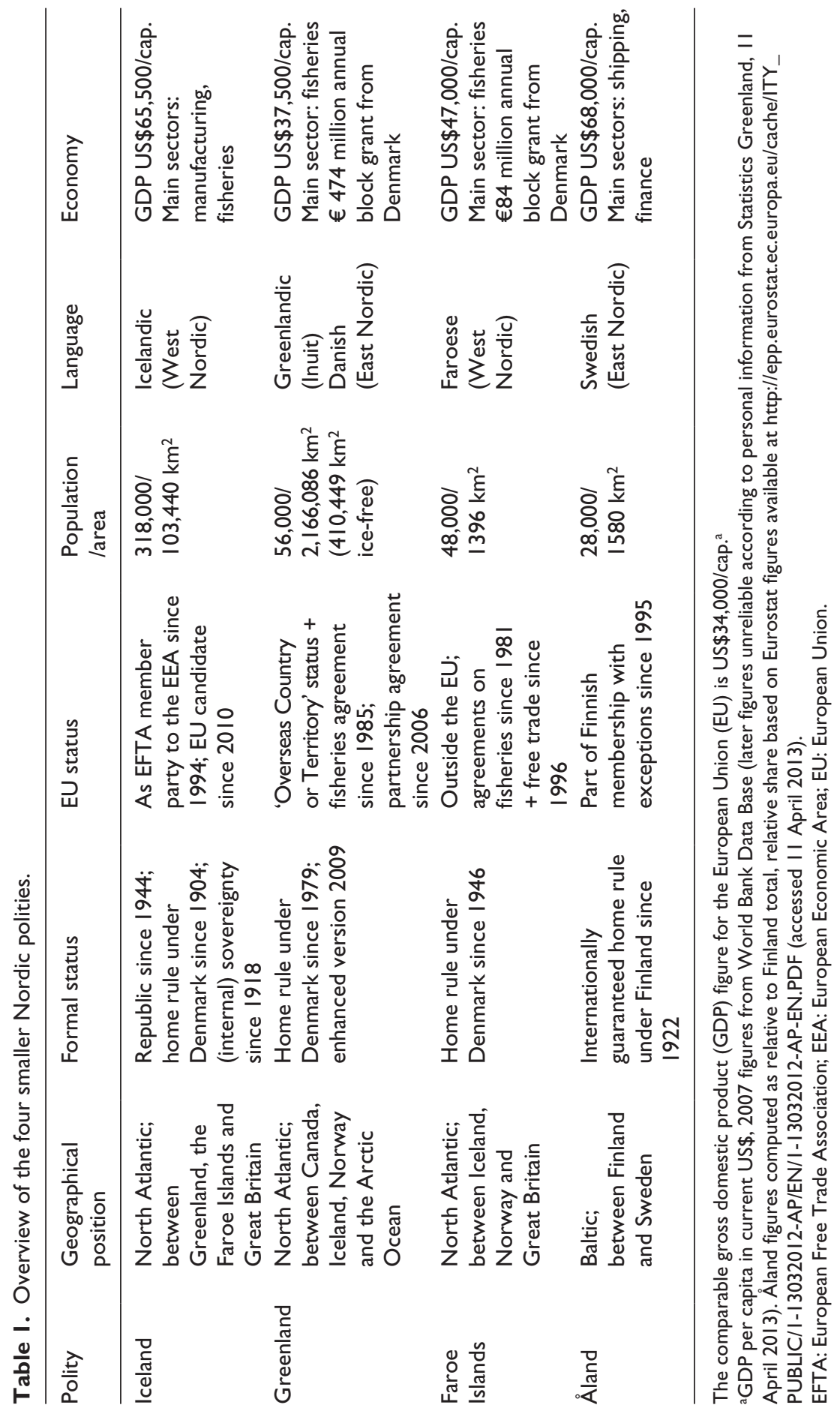


This leads to a new interpretation of the Nordic region and its postimperial relations affecting not only past but also current politics in Europe.

The cases examined are still or have recently been subjected to the authority of one of the four 'larger' Nordic states. However, the selected cases represent a range of possible politico-legal statuses. On the one end of the spectrum is Iceland, a formally sovereign state; on the other end is the dependency of Åland, a self-governing territory without any sovereign pretensions. Differences in formal status play a major role, of course, but they alone cannot account for the politics surrounding these former colonies. Sovereignty assumes different and shifting meanings in the different polities.

Distracted by a simplistic either/or concept of sovereignty where non-sovereign entities pass below the radar, current IR scholarship produces an empirically cursory and theoretically narrow understanding of world politics and the Nordic region. In addressing this problem, the overall contribution of this special issue is twofold.

Firstly, it offers a theoretical framework for the study of postimperial relations wherein sovereignty is a key issue. This framework can be used more generally for understanding relations between core and periphery in an empire under devolution. In the public debates in Iceland, Greenland, the Faroe Islands and Åland, direct references to sovereignty, independent agency and submission are central. As shown in Figure 2, the question of sovereignty constitutes a distinct axis, co-organizing parliamentarian and electoral politics along with the traditional, economic left-right axis. Yet before assuming any automatic meaning and consequences of this constant allusion to sovereignty, we suggest opening up the concept. What does sovereignty mean in the context of dissolving Nordic empires and increased European integration? Some territories may want to remain within the old empire. Others may use the concept of sovereignty as a bargaining chip without wanting independence ever to become reality. To begin exploring what sovereignty can and could mean for former colonies and peripheral possessions in Norden, we develop the notion of postimperial sovereignty games.

Secondly, this special issue applies this approach to the four cases in a systematic comparison between the cases. This leads to a more nuanced portrait of Norden and the relationship between postimperialism and the European integration process. Thus, this special issue shows that it is impossible to understand Nordic foreign policy regional dynamics without taking the imperial legacies into account.

The remainder of this introduction is organized in three parts. The first section explores the rosy pictures of Norden currently dominating IR accounts (particularly international political economy (IPE), security studies and European integration studies). We contrast these images with the rather different image provided by postcolonial studies. The second section presents our theoretical framework for understanding the sovereignty games taking place in the triangular relations. The theoretical framework allows for an analysis of how micro-polities manoeuvre between different centres. The third section provides a brief overview of the case studies in the special issue.

\section{Myths of the Nordic region in IR theory and beyond}

This section critically reviews the IR literature on the Nordic region. It argues that dominant accounts of the Nordic region in IR are lopsided because they disregard imperial 
legacies and current dynamics of postimperialism in the Nordic region. IPE, security studies and European integration studies uphold the various myths of the Nordic region as peaceful and homogenous in different ways and for different reasons. This is why we seek inspiration from postcolonial studies, which provide a very different analysis of Norden than that which is usually found in IR theory.

\section{Norden in international political economy: developed welfare society}

IPE scholars increasingly acknowledge that their understanding of the Nordic model is 'mythological' (Ryner, 2007). The general story presented by IPE scholarship is that during the Cold War the position between East and West helped promote a unique socio-economic configuration: the mixed economies of the Nordic universal welfare states (Browning, 2007: 35; Joenniemi and Lehti, 2003: 133). Esping-Andersen's (1990) identification of a 'social democratic welfare capitalist regime cluster' is an ideal-type description of the Nordic states, which has stuck also after the end of the Cold War. The same goes for Katzenstein's (1985) influential claim that 'democratic corporatism' leads to a remarkable 'economic success' in a handful of small and flexible European economies, including Denmark, Norway and Sweden. Katzenstein (1996: 130-134) later characterized the Nordic region as 'tiny and tidy' when compared with most other attempts at region-building. The 'varieties of capitalism' perspective (Hall and Soskice, 2001) groups the Nordic countries under the label of 'coordinated market economies'.

Recently, a detailed case study of Denmark, evaluating Katzenstein's claim, ascribed the success of democratic corporatism to the social homogeneity of the Nordic states (Campbell et al., 2006). Within the identity formations in the Nordic states, this idea of homogeneity involves a special role for the figure of 'the peasant', popular education as part of an Enlightenment Bildung project, an image of the state as a tool for reform to the benefit of all strata, and, last, but not least, a special place for the notion of ' $f o l k$ ', a notion somewhat similar to the German Volk, as a historical integrator of nations across social classes (Sørensen and Stråth, 1997: 1, 6; cf. Hansen, 2002a: 216). This particular identity construction is linked to the idea of the welfare society or state. Consequently, despite drastic reforms leading to the increased liberalization and privatization of the Nordic economies, the Nordic welfare state is still seen as a strong and stable construction, 'blunting neoliberal retrenchment' (Swank, 2002: 159). In recent years, scholars have pointed out the growth in neo-liberal policies in areas such as the housing market (Mortensen and Seabrooke, 2008) and the rise of health inequality (Kvist et al., 2012) that transform the Nordic welfare states. Notwithstanding the growth of New Public Management discourses and practices in Norden and the "underlying structural weaknesses of Nordic political economy in the context of a "globalised", "post-industrial" and "information economy" (Ryner, 2007:65), the Nordic region continues to be seen as a unique and attractive model when it comes to socioeconomic governance (Ryner, 2007: 65). The economic inequalities and social problems related to the postcolonial polities are somehow forgotten. In sum, IPE scholars still need to engage critically with some of the darker sides of Norden and its particular dynamics of dependency and domination. 


\section{Norden in security studies: model security community}

Not only in socio-economic, but also in security terms, the Nordic Sonderweg (Sørensen and Stråth, 1997: 1) stands out. As Wæver (1997b: 72) puts it, Norden is 'probably the standard example of an uncontested security community'. During the Cold War, the Nordic countries appeared to cooperate peacefully. They found a sophisticated way of arranging themselves between the superpowers, reaching from NATO membership on the one hand (Denmark and Norway) over Swedish neutrality to 'Finlandization'.2 Wiberg (1993: 211) notes how intra-Nordic history involves 'a series of non-wars'; that is, 'conflicts about issues that would typically lead to war, but were peacefully resolved'. Indeed, as Browning and Joenniemi (2004: 240) note, '[e]ver since Karl Deutsch et al. coined the concept in the 1950s, Norden has been a key example in the security communities literature ... the concept and implied explanations accounting for Norden's peaceful conditions have become almost a dogma and have been largely immune from contestation' As Schouenborg puts it, there is a 'remarkable absence of interstate and intrastate war in Scandinavia over the past 200 years', which marks the region out from the rest of Europe. Moreover, the Scandinavian states have demonstrated 'progressive internationalism or solidarist foreign policies' (Schouenborg 2013: 2; for a critical review, see Suzuki et al. 2013).

While recognizing that 'Norden is by no means problem-free', Joenniemi (2003: 198) maintains that 'it is now rather clear that the region stands out as a non-war community' that has passed beyond security to a-security (Joenniemi, 2007). Along similar lines, Parker (2002: 369) describes Norden as one of the most successful margins in relation to Europe as a centre and distinctively, according to Parker, 'remaining marginal to the system of colonialism'. So Norden is peaceful and harmonious. It is therefore hardly surprising that the idea of a 'Nordic model' became widespread internationally, also becoming part of the very self-perception of the Nordic countries (Sørensen and Stråth, 1997: 2). Strikingly, security scholars have hitherto made little more than passing reference to the fact that Norden does not just consist of Sweden, Denmark, Norway and Finland, but also a number of polities with their own political subjectivity and historical status (e.g. Greenland) that have and continue to play a major geostrategic role for the entire security landscape in the region (see Wivel, 2005). In sum, in theoretically inclined security studies there seems to be a kind of collective amnesia when it comes to the imperial past - and present - of Norden.

\section{Norden in regional and European integration studies: EU-sceptic region}

European and regional integration approaches see unproblematic cooperation between the large Nordic states and forget the independence movements and autonomy struggles. These perspectives can therefore describe a particular Nordic EU-scepticism without noticing that the autonomy struggles are sometimes quite attracted to the EU.

Norden is a region, a historically constituted unit of cooperation. This is the main message from the regionalization literature, and this has rendered it the object and case of interesting research. "There can be no doubt that "Norden" is essentially a discursive construction' (Götz, 2003: 324), yet it has been quite powerful as an ideology 
and discursive construction. Scholars working with 'new regionalism', understood as intensified regionalism and region-building after the end of the Cold War (e.g. Hettne et al., 1999; Wagstaff, 1999), made Norden one of their favourite cases. Constituted as a region in institutional, economic and identity terms, the Nordic countries appeared to be an ideal type for the kind of post-sovereign region-building that the 1990s were half describing, half dreaming of (e.g. Hettne et al., 1999; Katzenstein, 1996).

Yet the idea of a common Norden was actually most popular during the Cold War, and there has never really been unconditional enthusiasm for the idea, as such. As Miles (1998: 131) notes, while the North may be a well-functioning security community, national identity politics in the Nordic countries has to a large degree prevented the development of a closer regional integration between the Nordic states on defence matters and the like.

More strikingly perhaps, most studies of Nordic region-building tend to gloss over the colonial and imperial aspects, thereby confirming, with few exceptions, that Norden is a region of peace. Götz' (2003: 340) formulation is exemplary in this regard:

In the case of Norden we are dealing with a comparatively homogenous and historically stable region, which is rather easily distinguishable. Because of its location in the European periphery and its long coastline, most of the borders of the Nordic countries have not been object to significant changes in a historical perspective, especially not if we are talking about the borders of Norden against the outside world.

Another dimension of the 'new regionalism' agenda concerns the fragmentation of the nation state due to sub-state regional identities and movements. In the last two decades, studies have shown how the EU affects regional autonomy movements. This is happening in countries such as France and Spain (e.g. Börzel, 2003), as well as in the new member states in Central and Eastern Europe (Brusis, 2002). The overall argument advanced in these studies is that the EU both favours and helps contain movements of regional autonomy by promoting regional cooperation and self-determination through, for instance, structural funds to disfavoured regions and the protection of sub-state language minorities within the member states (see Jeffery, 2000; Keating, 1998, 2001). There are, however, no analyses of the impact of the EU on autonomy movements in Norden. ${ }^{3}$ This is surprising, given that there are important separatist and autonomy movements in all the three Nordic EU member states.

Indeed, as the contributors to this special issue demonstrate, these movements have led their sub-state polities to differentiate themselves from their metropole by, among other things, a particular relationship to the EU. Consequently, the Nordic autonomy movements should be relevant to integration scholars who focus on the relationship between regional autonomy and the EU.

When European integration scholars have analysed the Nordic member states, however, they have instead focused on Nordic EU-scepticism: from Norway's rejections of EU membership to the Danish and Swedish choice to remain outside the euro. In EU studies, the Nordic countries are generally seen as uniting 'an emotional attachment to the North' and to the Scandinavian welfare model with 'the economic attractions of the EEC' (Miljan, 1977, quoted in Hansen, 2002c: 50). The so-called 'welfare euroscepticism' is a criticism of market-driven integration, which 
undermines generous national welfare systems and public service in the North (Raunio, 2010: 188). Ingebritsen shows how differences between the EU policies of the Nordic states can be explained mainly as a consequence of how each country's leading economic sectors are affected by the integration process, and also how they exercise their political influence (Ingebritsen, 1998).

More nuanced analyses become possible when identity is seen as relational rather than absolute. Neumann (1994: 66) describes Norden as a region constructed by 'clashing interpretations' put forward by insiders and outsiders, each trying to modify the region to their own advantage. Although he adopts a radical constructivist approach, Neumann's (1994: 60ff) account of the dominant narrative still involves the well-known characteristics: welfare, peace, informality, moral superiority and benevolence. More generally, reflectivist scholarship finds that Nordic identity has been constructed using a series of contrasts to Europe: progress-conservatism, egalitarianism-hierarchy, LutheranismCatholicism, light-darkness (Sørensen and Stråth, 1997: 20). Indeed, Nordic identity is about being better than Europe (Wæver, 1992: 77). While opening up theoretically for future reconstruction, radical constructivist accounts of the past in effect reproduce a selfimage of Norden without any contradictions. ${ }^{4}$

More recent works in the same tradition contrast how different national identity narratives in the Nordic countries construct 'Norden' and 'Europe'. Central to this question is the relationship between legitimacy and sovereignty (Lord and Harris, 2006; Lord and Magnette, 2004; Weiler, 1999). Arguably, the Nordic attachment to sovereignty is linked to the idea that democracy is impossible beyond the nation state (Lawler, 1997). The landmark volume European Integration and National Identity (Hansen and Wæver, 2002) analyses the layered structures of national discourses in the Nordic states on how they should relate to Europe. The editors explain how the Nordic countries 'share a number of characteristics', such as size, geopolitical location and political culture. They are welfare states and 'nation-states with high degrees of ethnic homogeneity' (Hansen, 2002b: 11). While the book offers a rich analysis of national identity formations in relation to Europe, there is little mentioning of the former colonies and home rule areas.

However, even when this picture of Norden as consisting of only ideal-type nation states is not taken at face value, the result may still be that Norden appears as unique. One example is how Joenniemi and Lehti evaluate Norden and recent alternative attempts at conceptualizing a 'Northern Europe' with what is presented as a 'postmodern' yardstick (i.e. with a disregard for centres, borders, unequivocal identity, etc.). Even this perspective allows an evaluation of Norden as comparatively progressive (cf. Browning and Joenniemi, 2012; Joenniemi and Lehti, 2003: 132; Parker, 2002: 372).

However, European Integration and National Identity does point out differences in how Europe is constructed in the four countries. These differences indicate that the image of the Nordic states constituting a homogenous group does not hold. Most importantly, Finland's approach to the EU is clearly distinct from the other three countries. Firstly, the Finnish case study points out the problems involved in simply assuming any linkages between homogeneity, successful benevolence and euro-marginality: Finland shares the Nordic image of successful benevolence but is arguably less eurosceptic than the other Nordic countries (Joenniemi, 2002: 182). Moreover, when it comes to homogeneity, Finland does not qualify - at least not in the terms of ethnicity and language that are central to the other Nordic national identities (Browning, 2008: 89-93, 144-147; 
Joenniemi, 2002: 194, 198) if maybe in terms of socio-economic equality. Crucially, the Finnish case - in contrast to Denmark, Sweden and Norway - directs our attention to the distinct postimperial experiences of the Nordic countries: how Finland as a cultural nation, rather than as a nation state, 'during its formative years had to articulate itself and create a subjectivity outside of statist structures and to some extent even in opposition to statism' (Joenniemi, 2002: 209) in order to avoid provoking Russian imperialism; how this 'turned out to be a valuable resource to be drawn upon during periods of transition' (Joenniemi, 2002: 202), since it 'allowed for a rethinking of nation and state on separate levels once "Finland" was faced with the challenge of European integration' (Joenniemi, 2002: 214). To consistently construct such a postimperial perspective on Norden, however, we must venture outside IR and seek inspiration in postcolonial studies.

\section{Norden in postcolonial studies: disciplining the subaltern}

Within IR, the postcolonial perspective has led to a critique of the traditional perceptions of sovereignty and conceptualized the weak states left by decolonization as an expression of a 'pathological form' of sovereignty (Spruyt, 2005; Turner, 2002). Other strands of postcolonialism explore, both in more abstract terms as well as in more diverse locales, how the colonized can acquire sovereignty, subjectivity or agency (Bhabha, 1994; Saïd, 1978; Spivak, 1988; Sylvester, 2006). ${ }^{5}$ When approached from a postcolonial perspective, the image of Norden becomes much less rosy than in the above-mentioned strands of IR theory.

Indeed, postcolonial scholars from outside IR remind us that the Nordic countries are also deeply embedded in practices of subordination of the 'primitive' within and beyond their own territories (even if erased from public memory) (Bregnsbo, 2008: 77; Ghose, 2008: 417ff; Hauge, 2005; Jensen, 2008: 62; Larsen and Thisted, 2005: 67; Palmberg, 2009). Recent years have shown a renewed interest among historians for the old tropical colonies of the Nordic countries (Bregnsbo, 2008: 79; Ghose, 2008: 418) and Nordic involvement in the colonial ventures of other European states (Thygesen, 2005). Social scientists have gradually accepted the view that Finland practised 'internal colonization' through the ways in which the Sami people have had to retreat from the south of Finland to Lapland (Keskinen et al., 2009: 21). Literary scholars have turned our attention to how Greenlandic authors have appropriated Western forms in attempts to gain a voice vis-àvis the Danish colonizers (Thisted, 2005). It has also been demonstrated how various forms of colonialism continued in Greenland, for instance in the public administration, even after Home Rule was established in 1979 (e.g. Petersen, 1995).

Increasingly, these efforts to understand Norden as postcolonial are oriented towards contemporary practices of hybridization, mimicry and the political negotiation of identities (Gad, 2009a, 2009b; Langgård, 2003; Loftsdóttir and Jensen (eds), 2012; Körber, 2011; Petersen, 1998, 2006; Rantonen and Savolainen, 2002). The critical attack on the perception of the Nordic area as consisting of nation states - homogenous in past and present has aptly been condensed in the alternative label 'postcolonial conglomerate states' (Hauge, 2005: 61; Petersen, 2006: ch. 7). This is the predicament we label 'postimperial'. This special issue focuses on the implications of this predicament for sovereignty. 


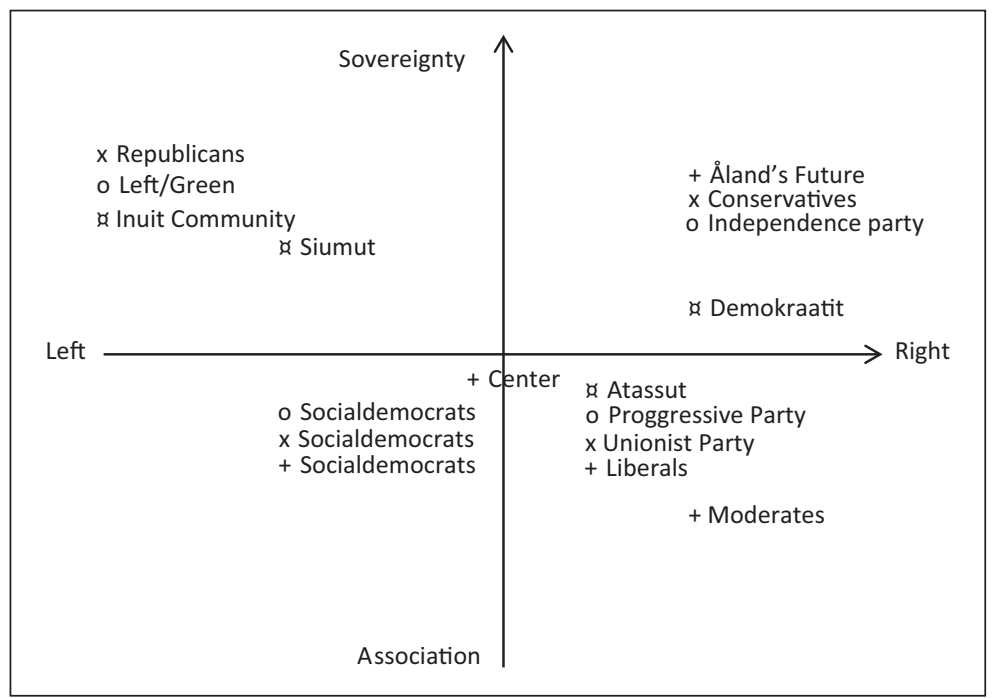

Figure I. The party systems of Iceland (o), the Faroe Islands (x), Greenland (a) and Åland (+) are organized along two distinct axes: $(X)$ a traditional economic right-left wing axis; $(Y)$ an axis defined by the emphasis given to questions of sovereignty and national identity.*

*The exact composition of the $Y$-axis depends on whether the domestic sovereignty games are primarily played out in relation to the metropole state or the European Union. The fixation of the individual parties along the axes represents a rough approximation, as some have moved considerably over time. Only the parties most significant over time are included (cf. Ackrén and Lindström, 20I2).

\section{Towards a postimperial perspective}

In the previous sections, we have argued that colonial and imperial dynamics are not part of existing IR accounts of the Nordic area. Consequently, Norden appears strikingly innocent. Moreover, while postcolonial scholars have examined cultural, legal, political and social struggles in the former colonies or territories in Norden, they have generally avoided the question of European integration. This is problematic given that, as this special issue demonstrates, the EU plays an important part in their attempts to negotiate political subjectivity: not only in relation to their former colonizer, but in international politics more generally. In a number of different ways, the EU provides a way for these territories to gain a more or less sovereign voice.

Figure 1 provides an overview of the existing images of Norden within different strands of IR theory: the Nordic countries are portrayed - and portray themselves - as exceptionally peaceful, successful and benevolent, both domestically and internationally. Secondly, they present themselves as exceptionally homogenous nation states. Thirdly, they are generally seen as particularly sceptic when it comes to the European integration process. The images promoted by postcolonial studies - as recollected above - clearly do not fit the images provided by IR. Hitherto, postcolonialism and European integration studies have lived separate lives despite their similar ways of questioning a series of concepts central to IR (Wæver and Tickner, 2009: 3). The contributors address 
this mutual ignorance by bringing together insights from European integration studies and postcolonial studies to understand how the home rule territories manoeuvre internationally.

Contrary to existing research, we do not approach the four larger Nordic countries as a periphery in relation to Europe, but as centres in relation to the smaller Nordic polities. Inspired by postcolonial studies of Norden, we want to explore Norden from its own periphery. The first thing to happen when applying a postimperial perspective is that Norden becomes bigger. We must then extend the list of cases from the four 'large' Nordic states - Sweden, Denmark, Norway and Finland - which are of interest to standard IR accounts of Norden, also including Iceland, Greenland, Aland and the Faroe Islands. ${ }^{6}$ Norden, in a postimperial perspective, includes eight rather than four 'countries'.?

This special issue concentrates on the understudied four small 'latecomers'. What image of Nordic-EU relations emerges if examining them from the perspective of the margin of Norden - from the small, postimperial countries related (in past and/or present) to the 'large' Nordic countries? The next section develops a theoretical framework for understanding the triangular relations between the EU, the small postimperial Nordic countries and the Nordic metropoles.

\section{Theoretical framework: postimperial sovereignty games}

Sovereignty dominates how we think about world politics. It leads us to think of relations in terms of either hierarchical subordination or external equality. For political practitioners, this leads to blindness to other forms of political organization. For academics, it leads to blindness to what (also) goes on in politics - in international politics, in domestic politics and particularly in the politics on the border between the international and the domestic. The aim of this section is therefore to develop a framework that provides a better account of what goes on in the triangular relations between the EU, the four 'large' Nordic states (whether EU member states or associated to the EU) and the four smaller Nordic countries (formally sovereign or not).

Our main claim is that we need to qualify sovereignty: the either/or understanding of sovereignty must be questioned to allow for an analysis of its very negotiation. This move is performed by adding a concept of sovereignty games to the concept of sovereignty-as-either/or. These games involve strategies that may be played out with reference to sovereignty-as-either/or, and they may involve alternative types of polities in addition to sovereign states. Our approach builds further on the framework developed by AdlerNissen and Gammeltoft-Hansen (2008) and Gad and Adler-Nissen (2012), but applies it with a focus on the Nordic region and places greater emphasis on the imperial past as the basis for contemporary sovereignty struggles.

\section{Units: states, self-governing countries and empires}

Realist international theory appears to take the state for granted. According to Kenneth Waltz (1979: 97), sovereignty means that a state 'decides for itself how it will cope with 


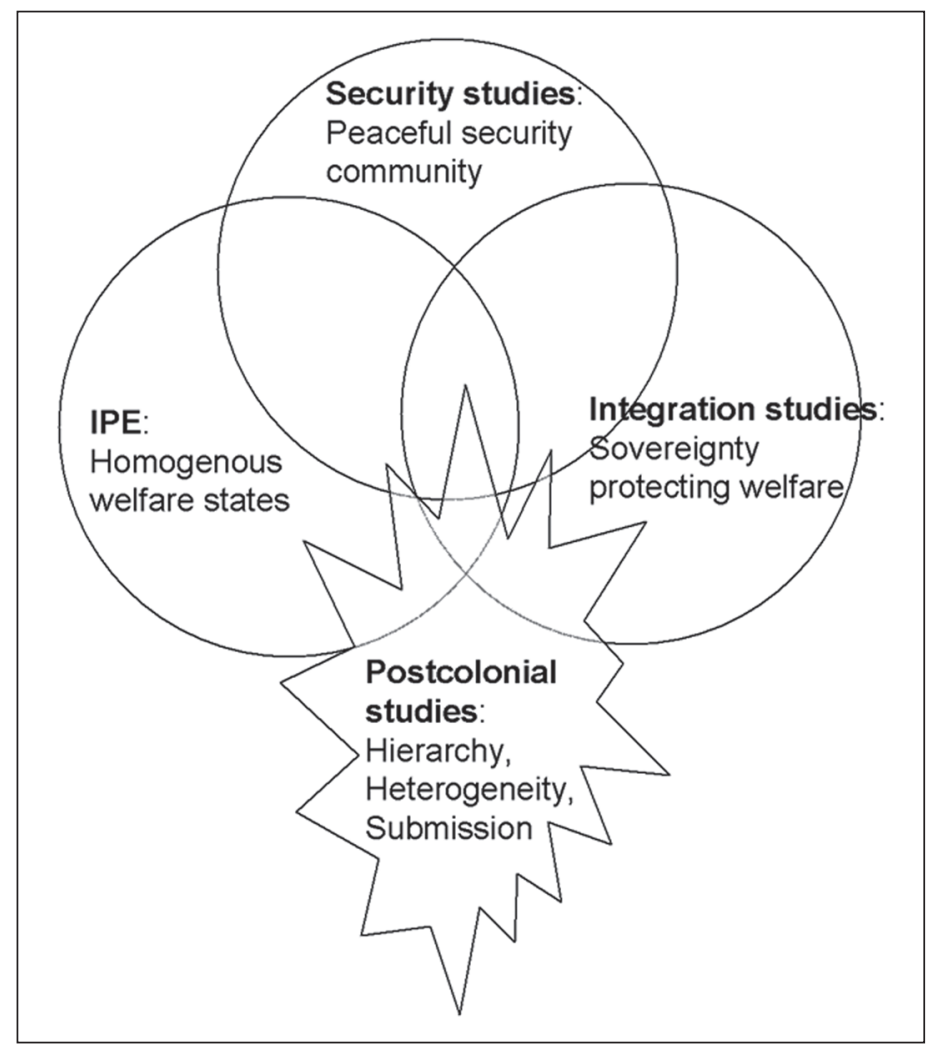

Figure 2. Different images of Norden in international relations theories and postcolonial studies.

its internal and external problems'. Morgenthau (1956 [1948]) echoes Carl Schmitt in insisting that sovereignty cannot be divided and may only be determined as a post-facto rationalization of some kind of 'real' power. ${ }^{8}$ This image of political life is peculiarly parallel to international legal theory. International law traditionally sees sovereignty as an either/or question: either the state is sovereign or not. From this perspective, sovereignty is the exclusive right to exercise, within a territory, the functions of a nation state and answer to no higher authority (Espersen et al., 2003: 142). In both realism and international law, the concept of sovereignty puts forward a choice of only two options when relating two units: either both are sovereign and therefore equal - or the one is hierarchically subjected to the other, which is therefore the only one of them that is sovereign. This explains why non-sovereign countries such as Aland or Greenland - through the lenses of realist IR scholarship as well as international law - are often observed only as objects. Arguably, when they are not sovereign, they have no separate agency (Browning and Joenniemi, 2008: 144).

Historians and sociologists, however, paint a different picture. To begin with, the concept of sovereignty has a diverse and uneven past. As Jens Bartelson (1995: 13) 
notes, "to start a history of sovereignty with a definition of the term sovereignty would be to subject its historicity to the sovereignty of the present, and hence to narrow the scope of investigation'. The conditions for sovereignty have even shifted over the last few decades (Barkin, 1998). Indeed, sovereignty should not be seen as a permanent situation. There are other ways of organizing the relationship between two entities than the either/or choice between equal sovereignty or sovereign hierarchy. This is what Ferguson and Mansbach $(1996,2008)$ discuss under the general label of 'polities'. Among these types of polities, two types stand out as immediately relevant for Norden: the traditional conceptualization of sovereignty is challenged when confronted with self-government arrangements (Petersen, 2006; cf. Baldacchino, 2010; Loukacheva, 2008: 6, 145) - and when confronted with the EU (Ruggie, 1993; Walker, 2003, 2008).

Firstly, being neither formally sovereign nor simply hierarchically subordinated to their metropole, the self-governing countries are political entities that do not readily fit the conceptual categories offered by the conventional theory addressing international politics and international law (Anghie, 2005: 38-39; Palan, 2003: 74). Self-government arrangements may even include the transfer of jurisdiction in some areas of foreign affairs (Loukacheva, 2008: 109) - an area traditionally so closely articulated to sovereignty that it is considered the prerogative of the sovereign.

Secondly, the EU is known as an 'unidentified political object'. As EU studies have grappled with the nature of the EU and its relation to sovereignty, three major perspectives have emerged. ${ }^{9}$ One perspective holds that, in the context of increased integration, the traditional understanding of sovereignty as territorial and inseparable should be replaced with the notion of 'late sovereignty'. This refers to functionally differentiated but overlapping authorities (Walker, 2003, 2008). A second perspective argues that Europe has moved beyond sovereignty; the notion of sovereignty is not the best way to conceptualize the present European political configuration. Ruggie (1993: 148-174) argues that the conduct of politics among EU members resembles the medieval form of rule with its 'overlapping forms of authority' and 'non-exclusive forms of territoriality'. The result is a post-sovereign Europe. ${ }^{10}$ To a third strand of scholars, the EU is best understood as a form of empire (Hansen and Jonsson, 2002; Zielonka, 2006). The notion of empire retains, on the one hand, some notion of a centre. On the other hand, the absolute territorial limits of the sovereign state are relieved by a notion of gradual fading 'from a central Cosmos to a peripheral Chaos' (Wæver, 1997b: 65, 86; cf. Motyl, 2001). The result is a polity, which is internally hierarchically structured in concentric circles of authority and influence (Tunander, 1997: 32).

Consequently, we are facing a perplexing encounter between two types of nonsovereign polities: the international organization (EU) and self-government arrangements. Such an analysis may be undertaken in a more nuanced manner when not blinded by the either/or concept of sovereignty; especially when taking into account that almost all epochs 'have been characterised by layered, overlapping, and interacting polities - coexisting, cooperating and/or conflicting' (Ferguson and Mansbach, 2008: 140) - and that such various historical forms of polities contaminate each other (Ferguson and Mansbach, 1996: 395; see also Parker and AdlerNissen, 2012). 


\section{Norden as a postimperial sovereignty configuration}

In contrast to both realist IR scholarship and traditional international legal thinking, the argument put forward in this special issue is that sovereignty cannot be understood as something either present or absent. Sovereignty is almost always present in some way or another when we speak of IR, but it unfolds in legal and political games as meaning production and praxis.

The home rule areas are of course constituted in relation to the idea of full, formal sovereignty. For these areas, the status as a 'properly decolonized' and sovereign state is a credible demand for the future. For Iceland, which gained independence from Denmark in 1944, no alternative to sovereignty is ever claimed; yet as Bergmann shows in this special issue, the possibility of non-sovereignty is nevertheless continuously present in Icelandic political debates. For Greenland, the Faroes and Åland, sovereignty continues to feature as an alternative to the present status; firstly, these countries are 'nation statelike': as islands they have a territory, even a very distinct one, courtesy of a more or less 'deep blue water' (cf. Harhoff, 1993: 470). They have a culturally distinct population. Internally, the home rule 'state' governs its territory and population and the population identifies with the 'state'. Externally, the 'state' represents its population - even if formally only vis-à-vis the metropole. However, these 'states' are not sovereign states, as they formally only qualify as bureaucratic extensions of their metropole.

However, meaning production and praxis relates not only to (the possibility of) sovereignty in these islands. To make sense of Norden, we need the notion of 'empire'. For example, the manner in which Greenlandic discourse establishes the relation to Denmark cannot, of course, be conceived as an equal juxtaposition of two sovereign nation states. However, it is just as impossible to conceive of this relationship narrowly as a hierarchical relationship between a centre and a periphery. It involves a postcolonial relationship with a continuous debate regarding the possibility of transforming it into a future of sovereign equality with Denmark. In other words, it is impossible to talk about the future of Greenland without also talking about its past status as a colony and its present status as a postcolony. The relation to Denmark is simultaneously one of past-perhaps-present imperial submission and future sovereign equality.

The Nordic home rule areas are, however, not just constituted in their - past, present and future - relation to their metropole. They are also constituted in relation to the wider international community, and in our case the EU. Formally sovereign Iceland is also constituted in relation to both the EU and its memories of submission to the DanoNorwegian empire. The EU has a deep impact on the relationship between the former colonizers and the former colonized in the North. In terms of late-sovereign relations to the EU, the four cases represent four different ways of articulating formal and substantial sovereignty: Iceland formally fully sovereign but substantially implicated in the EU through EEA membership; Åland part of the Finnish membership but with special arrangements, which actually endows Åland with a greater subjectivity than originally implied in the home rule arrangement; Greenland outside the EU proper but associated as an 'Overseas Country or Territory', dependent on Danish sovereignty and EU membership; and the Faroes with only a few bilateral agreements with the EU and its formal sovereignty deposited in Copenhagen. 
So we are interested in a specific configuration of polities: the four small Nordic countries and their relations to both their metropoles and the EU. We do not merely focus on a potential European empire, the Nordic empires-under-dissolution or the internal functioning of the political systems of the four countries. Instead, the object of study is the configuration of relations between, on the one hand, an EU in a late-sovereign relation to the larger Nordic states (which, as far as the EU relation goes, defies the concept of sovereignty as traditionally applied) and, on the other hand, the postcolonial relations between metropole and self-governing territory (which, as far as the formally non-sovereign home rule areas goes, also defies the concept of sovereignty as traditionally applied). Such configurations of polities are produced through negotiations of meaning and through the practical handling of the relations: through games.

\section{Conceptualizing sovereignty games}

Sovereignty can be played strategically, and this section outlines how this can be conceptualized with the notion of sovereignty games. In the on-going attempts at manoeuvring between dependency and self-determination, 'sovereignty' is a unique card that can be played - or played on - in a number of different ways by Iceland, Greenland, the Faroes, Aland, the metropoles and the EU. For instance, we might observe how sovereignty is not always an asset; it can also become a liability. Whereas sovereignty is traditionally perceived as a claim regarding ultimate authority over a specific territory, the exercise of sovereignty is also about maintaining control; and in some instances avoiding responsibility in a world in which authority moves up and down between different judicial and political levels and exercised horizontally outside of the state territory (Adler-Nissen and Gammeltoft-Hansen, 2008). In other words, that which is decisive for the manoeuvring room of contemporary states and state-like polities is not the absolute authority over their territories, but rather the manner in which they (and the polities to which they relate) selectively apply the concept of sovereignty in order to strengthen their control over certain policy areas and delegate the responsibility for others (Gammeltoft-Hansen and Adler-Nissen, 2008: 3).

We approach sovereignty from a discursive perspective. With the notion of 'game', however, we include a notion of players with strategies. Some of the players certainly have goals that they seek to achieve. However, games also involve moves that are not rationally directed towards any aim that may be meaningfully conceived as included in the game. We begin our understanding of sovereignty games by conceptualizing sovereignty as a Wittgensteinian language game. ${ }^{11}$ In so doing, we build on a number of IR scholars, including liberals (Sørensen, 1999) and radical constructivists (Aalberts, 2004, 2010; Fierke and Nicholson, 2001), who have used Wittgenstein to grasp the strategic use of language, that is, language games.

Wittgenstein distinguishes between the constitutive and regulative rules in language. For our purpose, the constitutive rule in sovereignty games is constituted by the 'either/ or' distinction implied by the formal status of sovereign state. Based on this constitutive rule, a series of regulative rules have emerged over the years. Whereas the constitutive rule defines the game, the regulative rules may evolve, most significantly the criteria of admission to the interstate system, but also the distribution of roles between different 
kinds of players admitted. In Sørensen's analysis, three interrelated sovereignty games currently exist: a modern game (Russia and China are archetypical players), a postmodern game (quintessentially the EU, but the rest of 'the West' plays along) and a postcolonial game (weak states in Africa are ideal-type players).

Our perspective differs fundamentally from Sørensen's approach in three ways: firstly, we believe that more than three games can be played with the concept of sovereignty; secondly, some games compromise the very 'either/or' distinction, which constituted the game in the first place; and most importantly, Sørensen finds the intrinsic qualities of the individual entity to be decisive for the kind of sovereignty game played out. Accordingly, material (in)capabilities and (in)capacities render a game postcolonial. Conversely, our perspective seeks to explore situations wherein neither the choice of game nor the rules of each of the games are fixed. Strategic action - and coincidental side-effects - may lead to a change of the game.

Perhaps the most fitting metaphor for the kind of games we have in mind is that of a group of children in a playground making up the rules as they go along. Crucially, the metaphor does not imply that the games played are not serious business. Anyone with children knows that the games played in kindergartens without adult supervision can involve questions of life and death. All players participate in a general game, but they usually fan out in pairs or small groups to play their own partial games. There is no a priori grammar describing all possible moves, so there is room for evolution. Yet each move must have sufficient credibility for the other players to accept it - and there is an elaborate but distinct hierarchy among the players. Some moves require general acceptance - including that of certain central players. Other moves need only to be accepted by one specific player. Some players might have firm ideas about how the partial or overall game should develop; other players may have no long-term goal but a firm will in relation to a short-term goal; and yet other players just play along. We thus follow Wittgenstein when he reminds that 'is there not ... the case where we play and make up the rules as we go along? And there is even one where we alter them as we go along' (Wittgenstein, 1958: 39).

In line with this conceptualization of a game, a sovereignty game involves two or more players who, in their interaction, make strategic claims about authority and responsibility with reference to a traditional 'either/or' concept of sovereignty. Contemporary sovereign states and polities, which qualify as potential states, manoeuvre between dependence and self-determination - and sovereignty is a card that can be played in these manoeuvrings - or played on - in different ways. Notably, the articulation of the either/ or concept of sovereignty need neither be explicit nor affirmative in order for it to be vital for the game.

\section{Intersecting sovereignty games in Norden}

One special category of sovereignty games can be found in contemporary Europe. Within the EU, sovereignty - as laid out above - undergoes a particularly radical form of change in which the member states surrender competencies related to everything from financial and trade policy to environmental and judicial policy. In the EU, authority is - in this way - no longer only exercised territorially but functionally, as the exercise of power and 
authority rejects the conception of mutually exclusive territorial jurisdictions. The EU has become a late-sovereign complex of overlapping claims to sovereignty (AdlerNissen, 2009; Walker, 2008). This has considerable and concrete consequences for the room for manoeuvre available to the Nordic states and home rule polities. The coexistence of two ways of distributing and claiming sovereignty - linked to territory and functions, respectively - makes for games. They may lead to confrontational games over who should be the ultimate arbiter in specific cases (e.g. the constitutional battle between the German Constitutional Court and the European Court of Justice). They may also give rise to hide-and-seek games in which nobody wants to assume responsibility (GammeltoftHansen and Adler-Nissen, 2010). On the one hand, these games build on a traditional either/or concept of sovereignty; on the other, they end up compromising exactly the either/or character of this concept.

Another special category of sovereignty games is the postcolonial. Compared to the range of varying sovereignty in the EU, the standard postcolonial situation is rather different. Postcolonial sovereignty games are not merely concerned with the relational distribution of subjectivity (which is a general characteristic of all sovereignty games). What is at stake is whether one of the parties to the game should at all be considered a party. Should the former colony be awarded any subjectivity at all? Postcolonial sovereignty games pertain not (only) to some particular instance of distribution of authority or responsibility, but to the distribution of the very possibility of articulating authority and responsibility. Postcolonial sovereignty games, in our definition, involve the constitution of one of the parties as a party to the game.

The 'standard' version of postcolonial sovereignty games involves the acquisition of sovereignty. During the last half of the 20th century, in what could be seen as the first round of postcolonial sovereignty games, European states saw their empires collapse. Across the globe, the colonized reconstituted themselves into sovereign states. A second round of postcolonial games, then, takes place between the former colonizers and the now-decolonized but still dependent new states.

A residual group of entities are involved in a different postcolonial sovereignty game, but this game has yet to involve the formal achievement of sovereignty. Instead, it involves the acquisition of whatever a state-like entity may be able to acquire by not claiming sovereignty. Sutton (2008: 16) stresses that a status of autonomy without formal sovereignty will probably never allow a 'happy', uncontroversial relation to the metropole. The 'unhappiness' and the controversies might, however, be part of more complex games whereby the parties utilize the two available alternatives - equal integration in the sovereignty of the metropole and equal independent sovereignty - strategically in the on-going negotiations of the formally hierarchical relation. In terms of disturbing the traditional vocabulary, this game is different from the one played in the standard process of decolonization, because it necessarily compromises the traditional either/or concept of sovereignty. Paradoxically, it involves making independent claims to renounce independence.

The triangular relations between the small Nordic countries, their metropoles and the EU combine extreme disparities in terms of power and room to manoeuvre with a tendency towards the most powerful actors voluntarily limiting or redistributing their power. The self-image of the Nordic states as benevolent and non-conflictual makes them, on the one hand, exceptionally sensitive to claims to the contrary (cf. Kristensen, 2004). On 
the other hand, the respective self-images of the Nordic countries as unique, homogenous nation states complicate their relations to polities that do not fit into the perceived homogeneity. In the European laboratory for new ways of playing out sovereignty, the various formal statuses of the Nordic self-governing countries and Iceland constitute yet another layer leading to unique sovereignty games. Consequently, as objects of investigation, the Nordic home rule areas and Iceland offer an optimal opportunity to study intersecting sovereignty games.

\section{Methods and design}

This special issue presents a comparative study of the triangular relations between the small Nordic countries, their metropoles and the EU. We focus on the conditions of sovereignty between past empires and the EU, appearing as a prospective empire. We see Norden as a configuration of polities, which is both postimperial and peripheral to an emerging EU empire. Yet Norden is also structured by sovereignty: the future sovereignty of the not-yet-sovereign home rule areas; the still-recently acquired sovereignty of Iceland and the late-sovereignty of the metropole states, whether formal EU members or not. For an overview of the four cases, see Table 1.

The four case studies offer detailed studies of particular instances of the postimperial predicament. All follow a similar template: the authors highlight the specific characters of the case at hand and provide the background and context necessary for the analysis. The papers then each present a multi-sited case study. The methodological starting point for the case studies has been that sovereignty games - apart from their codified formalization in legal texts - can be studied by comparing the negotiation of meaning in public debate and in specific forms of diplomatic praxis (e.g. meetings, negotiations, documents). ${ }^{12}$ In all three situations, the concept of sovereignty may be played on in strategic ways. When one party to the triangular relation relates - in the same strategic move - to both of the two other parties, the two layers of sovereignty games intersect. To study these moves, three types of data material are analysed using three different analytical strategies, as recollected in Table 2.

\section{Outline of the special issue: Europe seen from Norden}

The most immediate conclusion that we can draw from the case studies is that full formal sovereignty does make a difference. As Eiríkur Bergmann (2014) shows, Iceland has liberated itself from its former Danish superior sovereign. Today, it is not submitted to a metropole in terms of law or identity discourse. Reykjavik does, however, relate to Oslo in ways that tend to re-establish the Norwegian capital as a 'mediator' in relation to a European empire. Firstly, Iceland is compelled to coordinate with Norway in the European Free Trade Association (EFTA) before engaging the EU via the European Economic Area (EEA). Secondly, Icelandic officials lament that the Norwegians tend to marginalize Icelandic positions when negotiations get tough. So the past experience of having been subdued shows up repeatedly in the relation to what is constructed to be a prospective metropole (the EU). The postcolonial predicament shows itself not just in a nationalist discourse projecting the past as a struggle for independence (Hálfdanarson, 
Table 2. Analytical foci and methods.

\begin{tabular}{llll}
\hline Method & Institutional analysis & Discourse analysis & Praxis analysis \\
\hline Site & $\begin{array}{l}\text { Formalized } \\
\text { sovereignty } \\
\text { Treaties, } \\
\text { constitutions, } \\
\text { delegation laws }\end{array}$ & $\begin{array}{l}\text { Negotiations of } \\
\text { identity discourse } \\
\text { Parliamentary records, } \\
\text { media debate, official } \\
\text { statements and policy } \\
\text { papers }\end{array}$ & $\begin{array}{l}\text { Diplomatic praxis } \\
\text { interviews with } \\
\text { representatives } \\
\text { of the case country, } \\
\text { the metropole }\end{array}$ \\
Analytical strategy & $\begin{array}{l}\text { Understanding the } \\
\text { institutionalization } \\
\text { of the triangular } \\
\text { relation as both } \\
\text { result of 'frozen' } \\
\text { strategies and point } \\
\text { of departure for } \\
\text { strategies and games }\end{array}$ & $\begin{array}{l}\text { Mapping competing } \\
\text { visions of collective } \\
\text { identity and strategies } \\
\text { for the triangular } \\
\text { relations, i.e. the public } \\
\text { meanings ascribed to } \\
\text { the position of the } \\
\text { case country vis-à- } \\
\text { vis the EU and the } \\
\text { metropole }\end{array}$ & $\begin{array}{l}\text { Mapping the self- } \\
\text { understanding, } \\
\text { negotiations and } \\
\text { strategies of the } \\
\text { officials involved in the } \\
\text { management of the } \\
\text { triangular relations - } \\
\text { focusing on diplomatic } \\
\text { procedures, practices, } \\
\text { correspondence, tacit } \\
\text { understandings }\end{array}$ \\
\hline
\end{tabular}

2004), but it also appears in the repeated, anxious insistence to be recognized as equal to other sovereign European states, rather than having qualifiers like 'micro-' or 'postcolonial' detract from sovereign equality. After all, in Iceland, as in the self-governing countries, the question of sovereignty constitutes a distinct axis co-organizing parliamentarian and electoral politics along with the traditional, economic left-right axis (cf. Figure 1).

In her analysis of the Faroese case, Rebecca Adler-Nissen (2014) shows how a new political discourse has emerged on the Faroe Islands, a discourse linking Faroese autonomy from Denmark with European integration. While the common fisheries policy appears to be a major obstacle, Europe is discursively constructed as a road to more independent subjectivity although, paradoxically, any closer association to the EU goes through Copenhagen. Full Faroese independence is not likely in the foreseeable future, but Brussels is increasingly envisioned as a way to allow Tórshavn an independent role on the global scene. Meanwhile, Denmark takes upon itself the role of the maternalistic, postcolonial protector when international and European campaigns against whaling threaten indigenous Faroese culture. The result is an internationalization and Europeanization of the postcolonial relationship.

As for Greenland, Ulrik Pram Gad (2014) finds that a discourse - and development in legal status - distinctly pointing in the direction of sovereignty may fruitfully be combined with, and even furthered by, a diplomatic practice, which allows the micro-polity to punch well above its weight by coordinating intimately with the metropole. Greenland is not part of the EU but uses its metropole's membership as a platform for enhancing its 
subjectivity in the context of visions of future climate change, intensive raw material extraction, new transportation corridors and new claims to sovereignty over the Arctic.

The Åland case, analysed by Pertti Joenniemi (2014), is particular. First of all, the postimperial legacy appears to have not resulted in aspirations for international subjectivity or sovereignty per se. Rather, Åland has reacted to explicit calls from the outside: increasingly since Finland's accession to the EU, Åland has been asked by Helsinki to decide on how to influence EU policies in order to uphold and exercise what had been conceived of as its exclusively internal autonomy. Secondly, and perhaps related, Åland stands out when compared to the two other home rule areas and Iceland with respect to the ease with which the relation to the EU has been accepted. Finland differs from the four 'large' Nordic states in terms of a more positive approach to the EU, even after the 2011 parliamentary success of the nationalist True Finns Party. This EU acceptance relates to Finland's distinct imperial experience: the Finnish transfer to Russian rule seems to imply greater tolerance for separation of state and nation (Hansen, 2002a; Hansen and Wæver, 2002; Joenniemi, 2002). This tolerance is important for Åland, as it has enjoyed a position between Finland and Sweden for decades, which may be seen as less marked by the discourse of sovereignty than other polities.

This stands in contrast to Iceland, the Faroes and Greenland. Their respective nationalisms were partly coined in the imperial capital of Copenhagen (Mortensen et al., 2006; Wåhlin, 1994). Even if they are all explicitly conceived in opposition to Denmark (Gad, 2005), the 'laundry list' of national diacritica - what makes nation states differentiate on exactly the same traits (Löfgren, 1989) - was for each of these polities the result of German romanticism processed through a Danish intellectual milieu, dominated by the Danish theologian NFS Grundtvig. Whether or not Neumann (2014) is warranted in dismissing the colonial wounds claimed by Icelandic and Faroese national discourse when compared to the ones inflicted on Greenland - the discourses are strikingly parallel: the ideal-type relation between state, nation, language, culture, religion and economy is for these post-Danish polities one of total correspondence. ${ }^{13}$

But where does this leave the EU? Whether the EU is late sovereign, post-sovereign or some kind of empire depends on the perspective. Seen from the margins, sovereignty still plays a role, even if it is 'late' and differentiated in new ways - simply because those outside the EU do not share or pool sovereignty in the same way as the EU member states do. Perhaps the best way to conceptualize the EU is as a late-sovereign empire. Where, then, is the periphery of the European empire? In the EU-as-empire literature, the periphery generally begins with the member states that have opted out of significant areas of cooperation; it includes new and prospective member states, and ends with the neighbouring states that struggle to uphold a vision of accessing the EU (Wæver, 1997a; Zielonka, 2008). In this view, the Balkans and Turkey are the quintessential periphery of a European empire: their subjectivity is constructed - especially by the EU, but also to a great extent by themselves - as a question of realizing their true identity by becoming one with the EU.

The analysis of Norden as a postimperial configuration shows how this is a narrow view of what constitutes Europe's periphery. Moreover, whether the EU's imperial traits are seen as attractive depends on the respective experiences with previous versions of European imperialism. The most important experience the world has had with European 
imperialism is not related to its neighbouring territories. Rather, it involved as the 'imperializable periphery' (Doyle, 1986: 19): Africa, the Americas, Asia and the Pacific. Moreover, we would add the North Atlantic islands and coasts on the edge of the Arctic. When observed from these parts of the world, imperialism meant colonialism; and colonialism meant denying the colonized a subjectivity. From this perspective, any kind of multi-level governance is less immediately appealing, whether framed as late sovereign or imperial. The struggle for decolonization generally meant a struggle to make the colonizers leave. To those decolonizing, the aim remains to replace European empires with independent sovereign states - preferably nation states.

Nevertheless, this goal of becoming an ideal-type nation state involves its own ironies. This is especially true for small polities that need to relate to larger polities, which see themselves as on the road leading, in some sense, beyond sovereignty: The 'large' Nordic nation states that emerged out of the Danish and Swedish empires seem to react with a bit of weariness and maybe even maternalistic leniency to the claims to (prospective) sovereignty of the North Atlantic home rule areas and even formally sovereign Iceland. Their logic seems to be: 'Well, well - we treat you so nicely, but if you insist on experiencing the harsh life of sovereignty, you're welcome.' In contrast, the EU follows the logic of a benign empire in the making by, on the one hand, accepting whatever constitutional arrangements the national identities demand, only, on the other hand, to facilitate the de facto expansion of the reach of the European supranational empire.

What makes Norden unique is perhaps not so much its peaceful and homogenous appearance but rather how its imperial legacy flies under the radar of both public and academic debates. This has broader implications. Firstly, it challenges the idea that Norden is a model security community and points out the flaws in a theory overlooking the imperial legacy of the Nordic region. Secondly, it leads us to ask whether the notion of a Nordic social model producing equality and harmony makes sense in light of the very different experiences of Iceland, Greenland, the Faroes and Åland. Thirdly, our findings suggest that no narrative or theory of European integration is complete without taking imperial and postimperial processes into account.

\section{Acknowledgements}

This special issue has benefitted from discussions with the participants in our twin project on the EU's overseas countries and territories (Adler-Nissen and Gad, 2013) at conferences generously hosted by the University of Copenhagen in 2009 and the University of Greenland in 2010. Furthermore, the introductory article received valuable comments from the International Relations group at the Department of Political Science, University of Copenhagen. We are also grateful for helpful and very constructive comments from the three anonymous reviewers and the journal editors. Olivier Rubin, Niels-Henrik Topp, Anders Blaabjerg, Josef Kajangmat and Najaaraq Kreutzman provided advice on the comparison of GDP figures, while Maria Ackrén discussed the party systems of the case countries with us.

\section{Funding}

This research was supported by the Danish National Research Foundation; the Carlsberg Foundation; the Augustinus Foundation; Stjerngren's Foundation and Letterstedska Foundation. 


\section{Notes}

1. Browning (2007: 28; cf. Kuisma, 2007) explains that the 'Nordic brand' is past its best-before date, implying that there was at some point a substance to the brand.

2. Other scholars stressed the diversity of the arrangement by conceptualizing it as a Nordic 'balance' (Brundtland, 1966; Noreen, 1983) or otherwise (e.g. Dörfer, 1997; Mouritzen, 1994). Even seemingly similar positioning in relation to institutionalized security - within NATO (Archer, 1996) or as 'neutrals' or 'non-aligned' (Beyer and Hofmann, 2011; Devine, 2011) - may gloss over different policies and rationales.

3. Ackrén and Lindström (2012) briefly touch upon the role of the EU in relation to the Greenlandic Home Rule but do not find reason to pursue the problematique in relation to the Faroe Islands and Åland.

4. Constructive work on a competing Baltic region-building project by roughly the same group of scholars at one point self-identified as a possible threat to Nordic regional identity on a number of levels (Wæver, 1997a): on a conceptual level, the Baltic region was conceived as much less sovereignty-based; on a more mundane level, the Baltic region-building project diverted resources from Nordic regional cooperation for a period of time.

5. For a critique of the first version of postcolonialism in terms of the other, see Grovogui (2009).

6. Miles (1996b: 8-9) makes the same observation under the heading 'Five plus three?': 'it is doubtful whether the Nordic countries can be restricted to an elite club of Denmark, Finland, Iceland, Norway and Sweden', yet the volume investigates only the five sovereign states.

7. There is no innocent vocabulary. When we settle for 'countries' to denominate our cases, it is because we want to take the queries of Iceland, Greenland and the Faroe Islands seriously. Under the umbrella of the West Nordic Council, they have all asked the Nordic Council and Nordic Council of Ministers to refer to their membership as 'stater og lande [states and countries]' rather than the hitherto official 'lande og områder [countries and areas]'. The Scandinavian 'lande' inevitably loses some of its polyvalency when translated, as it covers both the English 'land' and 'country'. Our choice is not innocent - most notably as it entails a delimitation of cases, which excludes the Saami, whose autonomy is less territorially defined, as well as alternative Inuit conceptions of sovereignty and territoriality (cf. Bæhrenholdt, 2007; Gerhardt, 2011).

8. See Moore (2011) for the importance of Schmitt's concepts of security and sovereignty for realist IR.

9. Our tripartition of the debate is parallel to Browning's (2005).

10. For a detailed account of this so-called 'neo-medievalism' and its relevance for contemporary IR, see Friedrichs (2001). 'Polycentric' is another label that basically conveys the same analysis of the EU; a set of interlocking legal orders with a constant battle for supremacy (MacCormick, 2004: 14f).

11. This represents a very different approach to games than that found in game theory. For an exploration of the contrast between these two understandings of games, see Fierke and Nicholson (2001).

12. The project thereby engages with both the linguistic turn within the social sciences and its notion that language is decisive for power relations and with the more recent turn to practice, which studies day-to-day human interactions and routines beyond or outside written texts (Schatzki et al., 2001).

13. Cf. parallel conclusions regarding the similarity of Danish and Norwegian nationalisms in Hansen (2002a: 215f, 2002b: 12). Had Finland obtained independence directly from Sweden without the 'Russian detour', which conceptually helped detach state and nation somewhat, a similar demand for coincidence might have made the Swedish-speaking minority in Finland more precarious - and the position of Åland more constrained. 


\section{References}

Aalberts TE (2004) The sovereignty game states play: (quasi-)states in the international order. International Journal for the Semiotics of Law 17(2): 245-257.

Aalberts TE (2010) Playing the game of sovereign states: Charles Manning's constructivism Avant-la-Lettre. European Journal of International Relations 16(2): 247-268.

Ackrén M and Lindström B (2012) Autonomy development, irredentism and secessionism in a Nordic context. Commonwealth \& Comparative Politics 50(4): 494-511.

Adler-Nissen R (2009) Late sovereign diplomacy. The Hague Journal of Diplomacy 4(2): 121141.

Adler-Nissen R (2013) The Faroe Islands: Independence dreams, globalist seperatism and the Europeanization of postcolonial home rule. Cooperation and Conflict.

Adler-Nissen R and Gad UP (eds) (2013) European Integration and PostcolonialSovereignty Games: The EU Overseas Countries and Territories. London: Routledge.

Adler-Nissen R and Gammeltoft-Hansen T (eds) (2008) Sovereignty Games: Instrumentalizing State Sovereignty in Europe and Beyond. New York: Palgrave Macmillan.

Anghie A (2005) Imperialism, Sovereignty and the Making of International Law. Cambridge: Cambridge University Press.

Archer C (1996) The NATO Nordics and the CFSP. In: Miles L (ed.) The European Union and the Nordic Countries. London: Routledge, pp. 260-272.

Archer C (1999) Nordic Swans and Baltic cygnets. Cooperation and Conflict 34(1): 47-71.

Archer C (2000) Euroscepticism in the Nordic region. Journal of European Integration 22(1): 87-114.

Bæhrenholdt JO (2007) Coping with Distances: Producing Nordic Atlantic Societies. Oxford: Berghahn Books.

Baldacchino G (2010) "Upside Down Decolonization” in sub-national island jurisdictions: questioning the "Post" in postcolonialism. Space and Culture 13(2): 188-202.

Barkin JS (1998) The evolution of the constitution of sovereignty and the emergence of human rights norms. Millennium: Journal of International Studies 27(2): 229-252.

Bartelson J (1995) A Genealogy of Sovereignty. Cambridge: Cambridge University Press.

Bergman A (2007) Co-constitution of domestic and international welfare obligations. Cooperation and Conflict 42(1): 73-99.

Bergmann E (2014) Iceland: a post-imperial sovereignty project. Cooperation and Conflict.

Beyer JL and Hofmann SC (2011) Varieties of neutrality: norm revision and decline. Cooperation and Conflict 46(3): 285-311.

Bhabha H (1994) The Location of Culture. London: Routledge.

Bjørnskov C (2008) Social trust and fractionalization: a possible reinterpretation. European Sociological Review 24(3): 271-283.

Börzel T (2003) States and Regions in the European Union: Institutional Adaptation in Germany and Spain. Cambridge: Cambridge University Press.

Bregnsbo M (2008) Denmark and its colonies: historiography. In: Poddar P, Patke RS and Jensen L (eds) A Historical Companion to Postcolonial Literatures: Continental Europe and its Empires. Edinburgh: Edinburgh University Press, pp. 77-80.

Browning C (2005) Westphalian, imperial, neomedieval: the geopolitics of Europe and the role of the North. In: Browning C (ed.) Remaking Europe in the Margins: Northern Europe after the Enlargements. Aldershot: Ashgate, pp. 85-104.

Browning C (2007) Branding Nordicity: models, identity and the decline of exceptionalism. Cooperation and Conflict 42(1): 27-51.

Browning C (2008) Constructivism, Narrative and Foreign Policy Analysis: A Case Study of Finland. Bern: Peter Lang. 
Browning C and Joenniemi P (2004) Regionality beyond security? The Baltic Sea region after enlargement. Cooperation and Conflict 39(3): 233-253.

Browning C and Joenniemi P (2008) Gibraltar, Jerusalem, Kaliningrad: peripherality, marginality, hybridity. In: Parker N (ed.) The Geopolitics of Europe's Identity. London: Palgrave Macmillan, pp. 141-158.

Browning C and Joenniemi P (2012) From fratricide to security community: re-theorising difference in the constitution of Nordic peace. Journal of International Relations and Development 16: $483-513$.

Brundtland AO (1966) The Nordic balance. Cooperation and Conflict 1(2): 30-63.

Brusis M (2002) Between EU requirements, competitive politics, and national traditions: re-creating regions in the accession countries of Central and Eastern Europe. Governance 15(4): 531-559.

Campbell JL, Hall JA and Pedersen OK (eds) (2006) National Identity and the Varieties of Capitalism: The Danish Experience. Copenhagen: DJØF Publishing.

Devine K (2011) Neutrality and the development of the European Union's common security and defence policy: compatible or competing? Cooperation and Conflict 46(3): 334-369.

Dörfer I (1997) The Nordic Nations in the New Western Security Regime. Washington, DC: Woodrow Wilson Center Press.

Doyle MW (1986) Empire. Ithaca, NY: Cornell University Press.

Espersen O, Harhoff F and Spiermann O (2003) Folkeret. De internationale retsforhold. Copenhagen: Chr. Ejlers Forlag.

Esping-Andersen G (1990) The Three Worlds of Welfare Capitalism. New York: Polity Press.

Ferguson YH and Mansbach RW (1996) Polities: Authority, Identities, and Change. Columbia, SC: The University of South Carolina Press.

Ferguson YH and Mansbach RW (2008) A World of Polities: Essays of Global Politics. London: Routledge.

Fierke K and Nicholsen M (2001) Divided by a common language: formal and constructivist approaches to games. Global Society 15(1): 7-25.

Friedrichs J (2001) The meaning of new medievalism. European Journal of International Relations 7(4): 475-501.

Gad UP (2005) Dansksprogede grønlcenderes plads $i$ et Grønland under grønlandisering og modernisering. Copenhagen: Eskimologis Skrifter nr. 19.

Gad UP (2009a) Post-colonial identity in Greenland? When the empire dichotomizes back - bring politics back in. Journal of Language and Politics 8(1): 136-158.

Gad UP (2009b) Un avenir postcolonial groenlando-danois? Trois scénarios pour la dissolution de la Communauté du royaume - et trois autres pour son maintien et sa modification. Nordiques 18: 69-87.

Gad UP (2014) Greenland: a post-Danish sovereign nation state in the making. Cooperation and Conflict.

Gad UP and Adler-Nissen R (2012) Introduction: postcolonial sovereignty games in the margins of Europe. In: Adler-Nissen R and Gad UP (eds) European Integration and Postcolonial Sovereignty Games: The EU Overseas Countries and Territories. London: Routledge, pp. 1-24.

Gammeltoft-Hansen T and Adler-Nissen R (2008) An introduction to sovereignty games. In: Adler-Nissen R and Gammeltoft-Hansen T (eds) Sovereignty Games: Instrumentalizing State Sovereignty in Europe and Beyond. New York: Palgrave Macmillan, pp. 1-17.

Gammeltoft-Hansen T and Adler-Nissen R (2010) Disclaiming sovereignty. Paper presented at ISA, New Orleans, Louisiana, February 2010.

Gerhardt H (2011) The Inuit and sovereignty: the case of the Inuit circumpolar conference and Greenland. Politik 14(1): 6-14. 
Ghose S (2008) Postcolonial Sweden. In: Poddar P, Patke RS and Jensen L (eds) A Historical Companion to Postcolonial Literatures: Continental Europe and its Empires. Edinburgh: Edinburgh University Press, pp. 417-423.

Götz N (2003) Norden: structures that do not make a region. European Review of History: Revue europeenne d'histoire 10(2): 323-341.

Græger N (2011) Norden in a changing global order. In: Tiilikainen T and Korhonen K (eds) Norden: Making a Difference? Possibilities for Enhanced Nordic Cooperation in International Affairs (FIIA report no. 29). Helsinki: Finnish Institute of International Affairs, pp. 25-39.

Grovogui S (2009) The secret lives of sovereignty. In: White L and Howland D (eds) The State of Sovereignty. Bloomington, IN: Indiana University Press, pp. 261-276.

Hálfdanarson G (2004) Discussing Europe: Icelandic nationalism and European integration. In: Thorhallsson B (ed.) Iceland and European Integration: On the Edge. London: Routledge, pp. 128-144.

Hall PA and Soskice D (eds) (2001) Varieties of Capitalism: The Institutional Foundations of Comparative Advantage. Oxford: Oxford University Press.

Hansen L (2002a) Conclusion. In: Hansen L and Wæver O (eds) European Integration and National Identity. London: Routledge, pp. 214-225.

Hansen L (2002b) Introduction. In: Hansen L and Wæver O (eds) European Integration and National Identity. London: Routledge, pp. 1-19.

Hansen L (2002c) Sustaining sovereignty: the Danish approach to Europe. In: Hansen L and Wæver O (eds) European Integration and National Identity. London: Routledge, pp. 50-87.

Hansen L and Wæver O (eds) (2002) European Integration and National Identity. London: Routledge.

Hansen P and Jonsson S (2002) Imperial origins of European integration and the case of Eurafrica: a reply to Gary Marks' 'Europe and Its Empires'. Journal of Common Market Studies 40(6): 1028-1041.

Harhoff F (1993) Rigsfoellesskabet. Aarhus: Klim.

Hauge H (2005) Vi havde et fort i Amerika. Kritik 178: 54-65.

Hettne B, Inotai A and Sunkel O (eds) (1999) Globalism and the New Regionalism. London: Routledge.

Ingebritsen C (1998) The Nordic Countries and European Unity. Ithaca, NY: Cornell University Press.

Ingebritsen C (2002) Norm entrepreneurs: Scandinavia's role in world politics. Cooperation and Conflict 37(1): 11-23.

Jeffery C (2000) Sub-national mobilization and European integration: does it make any difference? Journal of Common Market Studies 38(1): 1-23.

Jensen L (2008) Denmark and its colonies: introduction. In: Poddar P, Patke R and Jensen L (eds) A Historical Companion to Postcolonial Literatures: Continental Europe and Its Empires. Edinburgh: Edinburgh University Press, pp. 59-62.

Joenniemi P (2002) Finland in the new Europe: a Herderian or Hegelian project. In: Hansen L and Wæver O (eds) European Integration and National Identity. London: Routledge, pp. 182-213.

Joenniemi P (2003) Norden beyond security community. In: Archer C and Joenniemi P (eds) The Nordic Peace. Aldershot: Ashgate, pp. 198-212.

Joenniemi P (2007) Towards a European union of post-security? Cooperation and Conflict 42(1): $127-148$.

Joenniemi P (2014) The Åland Islands: neither local nor fully sovereign. Cooperation and Conflict. 
Joenniemi P and Lehti M (2003) The encounter between the Nordic and the Northern: torn apart but meeting again? In: Lehti M and Smith DJ (eds) Post-Cold War Identity Politics: Northern and Baltic Experiences. London: Frank Cass, pp. 127-144.

Jordheim H and Neumann IB (2008) Innledning. Imperium, imperialisme og en introduksjon til begrepshistorisk teori og praksis. In: Jordheim H (ed.) Imperium. Imperialisme. Oslo: Universitetsforlaget, pp. 7-37.

Katzenstein PJ (1985) Small States in World Markets. Ithaca, NY: Cornell University Press.

Katzenstein PJ (1996) Regionalism in comparative perspective. Cooperation and Conflict 31(2): $123-159$.

Keating M (1998) The New Regionalism in Western Europe: Territorial Restructuring and Political Change. Cheltenham: Edward Elgar.

Keating M (2001) Plurinational Democracy: Stateless Nations in a Post-Sovereignty Era. Oxford: Oxford University Press.

Keskinen S, Tuori S, Irni S, et al. (eds) (2009) Complying with Colonialism: Gender, Race and Ethnicity in the Nordic Region. Aldershot: Ashgate.

Körber LA (2011) Figurations of the hybrid. Julie Edel Hardenberg's visions for a postpost-colonial Greenland. In: Thomsen BMS and Ørjasæter K (eds) Globalizing Art: Place, Identity and Transnationalism in Contemporary Nordic Art. Aarhus: Aarhus University Press, pp. 183-202.

Kristensen KS (2004) Greenland, Denmark and the Debate on Missile Defense: A Window of Opportunity for Increased Autonomy. DIIS Working paper 2004/14, September. Copenhagen: Danish Institute for International Studies.

Kuisma M (2007) Social democratic internationalism and the welfare state after the "Golden Age". Cooperation and Conflict 42(1): 9-26.

Kvist J, Fritzell J, Hvinden B, et al. (eds) (2012) Changing Social Equality: The Nordic Welfare Model in the 21st Century. Bristol: Policy Press.

Langgård K (2003) Language policy in Greenland. In: Brincat JM, Boeder W and Stolz T (eds) Purism in Minor Languages, Endangered Languages, Regional Languages, Mixed Languages: Papers from the Conference on 'Purism in the Age of Globalisation', Bremen, September 2001. Bochum: Brockmeyer, pp. 225-256.

Larsen I and Thisted K (2005) Hvad er så postkolonialisme? Kritik 178: 66-70.

Lawler P (1997) Scandinavian exceptionalism and European Union. Journal of Common Market Studies 35(4): 565-594.

Löfgren O (1989) The nationalization of culture. Ethnologia Europaea 14(1): 5-24.

Loftsdóttir K and Jensen L (eds.) (2012) Whiteness and Postcolonialism in the Nordic Region: Exceptionalism, Migrant Others and National Identities. Farnham: Ashgate.

Lord C and Harris E (2006) Democracy in the New Europe. New York: Palgrave Macmillan.

Lord C and Magnette P (2004) E Pluribus Unum? Creative disagreement about legitimacy in the EU. Journal of Common Market Studies 42(1): 183-202.

Loukacheva N (2008) The Arctic Promise: Legal and Political Autonomy of Greenland and Nunavut. Toronto, ON, Canada: University of Toronto Press.

MacCormick N (2004) A Union of Its Own Kind? Reflections on the European Convention and the Proposed Constitution of the European Union. Edinburgh: Neil MacCormick.

Miles L (1996a) Conclusion. In: Miles L (ed.) The European Union and the Nordic Countries. London: Routledge, pp. 275-283.

Miles L (1996b) Introduction. In: Miles L (ed.) The European Union and the Nordic Countries. London: Routledge, pp. 3-12.

Miles L (1998) Scandinavian regionalism: the case of Sweden. In: Wagstaff P (ed.) Regionalism in the European Union. Exeter: Intellect Books, pp. 130-139. 
Miljan T (1977) The Reluctant Europeans: The Attitudes of the Nordic Countries Towards European Integration. Montreal, QC, Canada: McGill-Queen's University Press.

Moore T (2011) Citizens into wolves? Carl Schmitt's fictive account of security. Cooperation and Conflict 46(4): 502-520.

Morgenthau HJ (1956 [1948]) Politics Among Nations: The Struggle for Power and Peace. 2nd ed. New York: Alfred A. Knopf.

Mortensen A, Thór JT and Thorleifsen D (eds) (2006) København som Vestnordens hovedstad. Nuuk: Atuagkat.

Mortensen JL and Seabrooke L (2008) Housing as social right or means to wealth: the politics of property booms in Australia and Denmark. Comparative European Politics 6(3): 305-324.

Motyl AJ (2001) Imperial Ends: The Decay, Collapse, and Revival of Empire. New York: Columbia University Press.

Mouritzen H (1994) Testing weak power theory: three Nordic reactions to the Soviet disintegration. In: Carlsnaes W and Smith S (eds) European Foreign Policy: The EC and Changing Perspectives in Europe. London: Sage, pp. 156-177.

Mouritzen H (1995) The Nordic model as a foreign policy instrument: its rise and fall. Journal of Peace Research 32(1): 9-21.

Neumann IB (1994) A region-building approach to Northern Europe. Review of International Studies 20(1): 53-74.

Neumann IB (2014) Imperializing Norden. Cooperation and Conflict.

Nexon DH and Wright T (2007) What's at stake in the American empire debate? American Political Science Review 101(2): 253-271.

Norden.org (n.d.) Business and the economy. Available at: http://www.norden.org/en/the-nordicregion/business-and-the-economy (accessed on 7 September 2012).

Noreen E (1983) The Nordic balance: a security policy concept in theory and practice. Cooperation and Conflict 18(1): 43-56.

Palan R (2003) The Offshore World: Sovereign Markets, Virtual Places, and Nomad Millionaires. Ithaca, NY: Cornell University Press.

Palmberg M (2009) The Nordic colonial mind. In: Keskinen S, Tuori S, Irni S, et al. (eds) Complying with Colonialism: Gender, Race and Ethnicity in the Nordic Region. Aldershot: Ashgate, pp. 35-50.

Parker N (2002) Differentiating, collaborating, outdoing: Nordic identity and marginality in the contemporary world. Identities: Global Studies in Culture and Power 9(3): 355-381.

Parker N and Adler-Nissen R (2012) Picking and choosing the "Sovereign" border: a theory of changing state bordering practices. Geopolitics 17(4): 773-796.

Petersen H (1998) Lovgivningsvirksomhed under hjemmestyre - mellem fortid og fremtid. In: Petersen H and Janussen J (eds) Retsforhold og samfund i Grønland. Nuuk: Ilisimatusarfik, pp. 129-148.

Petersen H (2006) Retspluralisme i praksis. Copenhagen: Ilisimatusarfik/DJØF Publishing.

Petersen R (1995) Colonialism as seen from a former colonized area. Arctic Anthropology 32(2): $118-126$.

Rantonen E and Savolainen M (2002) Postcolonial and ethnic studies in the context of Nordic minority literatures. In: Gröndahl S (ed.) Litteraturens gränsland (Uppsala Multiethnic Papers 45). Malmö: Centrum för multietnisk forskning, pp. 71-94.

Raunio T (2007) Softening but persistent: Euroscepticism in the Nordic EU countries. Acta Politica 42(2-3): 191-210.

Raunio T (2010) The EU and the welfare state are compatible: Finnish social democrats and European integration. Government and Opposition 45(2): 187-207. 
Ruggie JG (1993) Territoriality and beyond: problematizing modernity in international relations. International Organization 47(1): 139-174.

Ryner M (2007) The Nordic model: does it exist? Can it survive? New Political Economy 12(1): 61-70.

Saïd E (1978) Orientalism. New York: Pantheon Books.

Schatzki TR, Knorr-Cetina K and von Savigny E (eds) (2001) The Practice Turn in Contemporary Theory. New York: Routledge.

Schouenborg L (2013) The Scandinavian International Society, Primary Institutions and Binding Forces, 1815-2010. London: Routledge

Shaw M (2002) Post-imperial and quasi-imperial: state and empire in the global era. Millennium: Journal of International Studies 31(2): 327-336.

Sørensen G (1999) Sovereignty: change and continuity in a fundamental institution. Political Studies 47(3): 590-604.

Sørensen Ø and Stråth B (eds) (1997) The Cultural Construction of Norden. Oslo: Scandinavian University Press.

Spivak G (1988) Can the subaltern speak? In: Nelson C and Grossberg L (eds) Marxism and the Interpretation of Culture. Urbana, IL: University of Illinois, pp. 271-313.

Spruyt H (2005) Ending Empire: Contested Sovereignty and Territorial Partition. Ithaca, NY: Cornell University Press.

Sutton P (2008) "The Best of Both Worlds": autonomy and decolonisation in the Caribbean. Working paper no. 2, August. London: Centre for Caribbean Studies, London Metropolitan University.

Suzuki S et al. (2013) The Scandinavian International Society by Laust Schouenborg. International Politics Reviews 1(1): 49-62.

Swank D (2002) Global Capital, Political Institutions, and Policy Change in Developed Welfare States. Cambridge: Cambridge University Press.

Sylvester C (2006) Bare life as a development/postcolonial problematic. The Geographical Journal 172(1): 66-77.

Thisted K (2005) Postkolonialisme i nordisk perspektiv. In: Bech H and Sørensen AS (eds) Kultur på kryds og tvaers. Aarhus: Klim, pp. 16-42.

Thorhallsson B (2004) Towards a new theoretical approach. In: Thorhallsson B (ed.) Iceland and European Integration: On the Edge. London: Routledge, pp. 185-208.

Thygesen P (2005) Kongospår. Norden i Kongo - Kongo i Norden. Stockholm: Etnografiska Museet.

Tunander O (1997) Post-cold war Europe: a synthesis of a bipolar friend-foe structure and a hierarchic cosmos-chaos structure? In: Baev PK, Tunander O and Einagel VI (eds) Geopolitics in Post-Wall Europe: Security, Territory and Identity. London: Sage, pp. 17-44.

Turner S (2002) Sovereignty, or the art of being native. Cultural Critique 51(3): 74-100.

Wæver O (1992) Nordic nostalgia: Northern Europe after the Cold War. International Affairs 68(1): 77-102.

Wæver O (1997a) The Baltic sea: a region after post-modernity? In: Joenniemi P (ed.) NeoNationalism or Regionality: The Restructuring of Political Space Around the Baltic Rim. Stockholm: NordREFO, pp. 293-342.

Wæver O (1997b) Imperial metaphors: emerging European analogies to pre-nation-state imperial systems. In: Baev PK, Tunander O and Einagel VI (eds) Geopolitics in Post-Wall Europe: Security, Territory and Identity. London: Sage, pp. 59-93.

Wæver O and Tickner A (2009) Introduction: geopolitical epistemologies. In: Wæver O and Tickner A (eds) International Relations Scholarship Around the World. London: Routledge, pp. 1-31. 
Wagstaff P (1999) Introduction: regions, nations, identities. In: Wagstaff P (ed.) Regionalism in the European Union. Exeter: Intellect Books, pp. 4-18.

Wåhlin V (1994) Island, Færøerne, Grønland og det nordiske. Den Jyske Historiker 69-70: 38-61.

Walker N (2003) Late Sovereignty in the European Union. In: Walker N (ed.) Sovereignty in Transition. Portland, OR: Hart Publishing, pp. 3-32.

Walker N (2008) The variety of sovereignty. In: Adler-Nissen R and Gammeltoft-Hansen T (eds) Sovereignty Games: Instrumentalizing State Sovereignty in Europe and Beyond. New York: Palgrave Macmillan, pp. 21-32.

Waltz KN (1979) Theory of International Politics. New York: McGraw-Hill.

Weiler JHH (1999) The Constitution of Europe. Cambridge: Cambridge University Press.

Wiberg H (1993) Scandinavia. In: Burns RD (ed.) Encyclopaedia of Arms Control and Disarmament, vol. 1. New York: Charles Scribner's Sons, pp. 209-226.

Wittgenstein L (1958) Philosophical Investigations. Oxford: Basil Blackwell.

Wivel A (2005) Between paradise and power: Denmark's transatlantic dilemma. Security Dialogue 36(3): 417-421.

Zielonka J (2006) Europe as Empire: The Nature of the Enlarged European Union. Oxford: Oxford University Press.

Zielonka J (2008) Europe as a global actor: empire by example? International Affairs 84(3): 471-484.

\section{Author biographies}

Rebecca Adler-Nissen is an Associate Professor at the Department of Political Science, University of Copenhagen. Her research focuses on IR theory (especially International Political Sociology), diplomacy, sovereignty and European integration, which has been published in journals such as International Organization, Review of International Studies and Journal of Common Market Studies. She is author of Opting Out of the European Union: Diplomacy, Sovereignty and European Integration (Cambridge University Press, 2014), editor of Bourdieu in International Relations: Rethinking Key Concepts in IR (Routledge, 2012) and co-editor with Ulrik Pram Gad of European Integration and Postcolonial Sovereignty Games: EU's Overseas Countries and Territories (Routledge, 2013).

Ulrik P Gad is a postdoctoral researcher at the Centre for Advanced Security Studies, University of Copenhagen, Denmark. From 1998 to 2002 he was employed by the Greenland Home Rule Government. Current research focuses on the identity politics and conflicts of Danish 'Muslim relations' and on the postcolonial relationship between Greenland and Denmark. Publications include European Integration and Postcolonial Sovereignty Games (with Rebecca Adler-Nissen (eds), Routledge, 2013), 'Preventing radicalisation through dialogue?' in Critical Studies on Terrorism (2012), a double special issue of Security Dialogue on 'The Politics of Securitization' (co-edited with KL Petersen, 2011) and 'Postcolonial identity in Greenland?' in Journal of Language and Politics (2009). 